\title{
Prosumption and Web 2.0 Challenges Faced by African Countries Users
}

\author{
Seydou Harouna Fatouma ${ }^{1}$, Shen Lei', Hamadou Tahirou Abdoulkarim² \\ ${ }^{1}$ Glorious Sun School of Business and Management, Donghua University, Shanghai, China \\ ${ }^{2}$ School of Economics and Management, Shanghai Maritime University, Shanghai, China \\ Email: sfatouka@gmail.com, slei@dhu.edu.cn, kalishufe@hotmail.com
}

Received 4 June 2016; accepted 15 July 2016; published 18 July 2016

Copyright (C) 2016 by authors and Scientific Research Publishing Inc.

This work is licensed under the Creative Commons Attribution International License (CC BY). http://creativecommons.org/licenses/by/4.0/

(c) (i) Open Access

\begin{abstract}
In recent years worldwide boundaries have been redefined, thanks to internet and technologies which facilitate increasingly the interaction between virtual friends and socials networking users. Consumers as well as producers in both developed and developing countries share information, pictures and videos via the Web 2.0 tools available on electronic devices and Internet websites. However due to several obstacles, activities such as co-creations, digital collaboration and others socials networking can be limited for some users. Thus this article discussed various factors that limit developing countries' prosumers interactivity in the age of Web 2.0 technology. The factors influencing numbers of users' collaboration can be individual, organizational, technological and/ or environmental factors.
\end{abstract}

\section{Keywords}

Web 2.0, Prosumers, Internet, Developing Countries

\section{Introduction}

Prosumption concept is the interrelation between production and consumption by involving the use of internet and Web 2.0. Under the Web 2.0, prosumption' tendency explodes increasingly as users have the ability to produce content collaboratively [1]. Similarly, Clay Shirky argues that "the consumer is the Internet's most recent casualty" and "we are all producers now." The availability of websites, search engines and information encourages users to create, to customize and to manipulate software for making products of their own, footage shot, music or film. Thus consumers and their equipment undoubtedly contribute to companies' success [2] [3]. According to Zwick et al. (2008) prosumption means that companies are granting new freedom to consumers to interact, and exchange information and ideas in virtual communities and networks sites. 
Yet the first significant contribution to conceptualizing prosumption was made by Alvin Toffler (1980) despite the fact that his study did not have a great impact on scholars. He was considered as a futurist ahead of internet tendency and his 1980 book, Third Wave was at some times the source of huge debate. Subsequently in the wake of Toffler's devotion, prosumption has become an important topic in the recent literature; scholars in diverse fields began to award greater consideration to the changes involved [1].

Several reasons and benefits justify the use of web 2.0 as sharing information through discussion groups, promoting social interaction, collective intelligence, creation of Internet subject guide, adding and updating content and information literacy [4] [5].

Others approaches focus on changing individual behavior by promoting awareness of environmental problems and, exhibiting "pro-environment behavior" consistent with sustainability [6]. Thus internet games and social networking can easily be an excellent strategy to boost users activities for instance in Niger where environmental, economical and social innovations are needed. This article presents some obstacles and challenges that limit web-based technology access for developing countries prosumers.

\section{Prosumption and Web 2.0 Tools}

Alvin Toffler (1980) was the first who focused attention on the term prosumer in The Third Wave; Toffler also illustrated that prosumption was predominant in pre-industrial societies. Similarly, Ritzer (2009) focused on what he called the Industrial Revolution, but he argued that production and consumption was never fully distinct as "producers consumed raw materials; consumers produced their meals". Recently prosumption theory has become a key subject in the academic literature. To describe the same phenomena many authors used or created similar concepts: do-it-yourself (DIY) (Watson and Shove, 2008); craft consumption (Campbell, 2005); ProAms (Leadbetter and Miller, 2004); co-creation (Prahalad and Ramaswamy, 2004a, 2004b); service-dominant logic (Vargo and Lusch, 2004, 2008); commons-based peer production (Benkler, 2006; Benkler and Nissenbaum, 2006); Cult of the Amateur by Beer and Burrows (2007); collaborative capitalism involving both value co-creation and service dominant logic (Cova, Dalli and Zwick, 2011); crowd- and open-sourcing (Howe, 2009); putting customers to work (Ritzer, 1993); all have in common the idea that contemporary industries put consumers to work on the internet [1]. And others prosumption concepts related to web 2.0 (Humphreys and Grayson (2008), Zwick et al. (2008), Xie et al. (2008), Ritzer and Jurgenson (2008). Yet prosumption theory is becoming popular among others. Prosumption involves production and consumption rather than focusing on production or on consumption, it associated social changes with the internet and Web 2.0 (Shifting from Web 1.0 provider-generated to Web 2.0 user-generated, social networking sites as Weixin, Youku, Facebook, Youtube), [1]. Undoubtedly, contemporary consumers (users) take part in corporations' production; most often they use their own devices for production for instance their computers, phones, cameras, camcorders etc. to produce content for Web 2.0 platforms. All of the results of their productions accessible for corporations involve consumers' co-creation. Consumers and their equipment unavoidably contribute to companies' success [2] [3].

There is a variety online revolution, particularly on the Web 2.0 which is generated by the user. Web 2.0 is combined to Web 1.0 as is provider-generated with the user-generated. Web 2.0 defined by the ability of users to produce content collaboratively [1]. The impressive outburst in prosumption has been on Web 2.0 in order to facilitate the range of production and consumption. Examples are classified into six social media platforms [7]:

$\checkmark$ Collaborative projects (e.g. Wikipedia where users generate articles and continually edit, update and comment on them [8].

$\checkmark$ Blogs and microblogs (e.g. Twitter-real-time information networks).

$\checkmark$ Video content communities (e.g. YouTube).

$\checkmark$ Social networking sites (e.g. Facebook, MySpace, and other social networking websites, where users create profiles composed of videos, photos, and text, interact with one another, and build communities [9].

$\checkmark$ Virtual game worlds (e.g. World of Warcraft) and virtual social worlds (e.g. SecondLife where users create the characters, communities, and the entire virtual environment [10].

$\checkmark$ Picture sharing sites (e.g. Weibo and Sina where mostly amateurs upload and download videos and photographs).

Others softwares include digital virtual games such as Rainforest Survival Challenge, WilderQuest Unplugged, In Search for Oldton which engage and entertain the players [11]. The key feature of Web 2.0 is communication in networks such as YouTube, Wikipedia and Facebook which are intensively popular all through 
the world and amid African communities.

1) Users can create videos and put them on internet which can be viewed by other users.

2) The second type characteristic of Web 2.0. RSS feed and MyGoogle: User generated content and shares the idea that information could be adjusted accordingly to individual needs.

3) The third type characteristic of Web 2.0 enables users to indicate their personal preferences: Personalization.

In today's creative and media industries Reality television shows like Big Brother provide a structure for consumers to intervene in the program both on and off the screen, through websites, chat rooms and message boards, phone-ins and onscreen text messages, spin-off programs and voting. Chris Bilton in his book "Management and creative industries" says "companies begin to outsource production and marketing, and as new channels of communication between producers and consumers open up, value chains in all areas of business have been reconfigured" [11]. There is a growing trend towards digital technologies in diverse activities, for instance business, education health care and environment [12]. For countries like Niger which consistently struggle with Sahara desertification and economic issues, access to online platforms could be useful for the population educational and recreational purposes.

Yet there is a need to organize the flowing from producers to consumers via web 2.0 in developing countries. In the following section we will discuss the various factors that limit developing countries prosumers participation and interactivity in the web 2.0 technology.

\section{Internet Usage Situation in Africa}

\subsection{Context}

In term of population and size, Africa continent is considered the second large one after Asia. With a total of 54 countries, Africa technologies usages are still limited when compared to the rest of the world. As internet is a vital tool for Web 2.0 systems, many authors studied its low penetration in Africa. 2014 Digital Statistics reported that internet users represent 55,930,391 (32\% of the entire population) and 11,200,000 citizens fully active Facebook users at a mobile subscription of 114,000,000 (65\%). Still, only South Africa has internet traffic figures similar to those of Europe and North America, few others countries Morocco, Egypt, Mauritius and Seychelles have a reliable internet technologies compare to most of African countries. Measurable parameters such as the number of ISP subscriptions, host number, network traffic, and available bandwidth indicate that Africa is stage behind the "digital development". According to Giancarlo Livraghi (2008), "in 2000, Subsaharan Africa as a whole had fewer fixed telephone lines than Manhattan, and in 2006 Africa contributed to only $2 \%$ of the world's overall telephone lines in the world" [13]. The International Telecommunication Union estimates, about $19 \%$ of the African population has Internet access compared to 32\% for Asia-Pacific and $65 \%$ for Americas [14]. Although social media use is in upward trend, Web 2.0 is only popular in capital or universities. A research of 54 tertiary institutions conducted in 27 African countries revealed that $47 \%$ have installed e-learning systems [15]. The implementation of learning tools seems reasonable; however their usage is low across the continent. A study in Ghana University reveals that among 74 lecturers, $66.2 \%$ did not have knowledge of Web 2.0 facility [16], and among those $33.8 \%$ who did know, only $10.8 \%$ knew how to access it due to lack of awareness, skills and time [16] [17]. International online inter-activities could allow African users to share their talents and fortunate consumers' creativity could be promoted by brands like Sony, Microsoft, 3G and Apple. Moreover online websites offer great potential for individual, organization and government to move beyond passive voyeurism to actively "co-create" or "prosume" images, games, advertisements and processes essential for changes [11].

\subsection{Web 2.0 Challenges}

According to Thomas and Thomas, (2012) in the last decade, social media growth and Web 2.0 technologies have a dramatic impact on how people communicate. Much of today's prosumption and e-commerce taking place on websites such as Alibaba vs Amazon, Youku vs Youtube, Flipkart, Rakuten, etc. could consequently integrate developing countries into the "information society", facilitate international communication and increase users global opportunities. Eventually artists can promote their work by advertising and organizing "virtual galleries". Activities such as online shopping, e-bank could help to reduce costs, save time and be more ef- 
ficient. However there are several obstacles that limit users' blogging and their competitive online market. Factors that affect prosumers collaboration are as following:

- Lack or inadequate infrastructures facilities: Various rural regions in Africa still lack licences and access to fibre-optic network. Poor infrastructure includes low Internet bandwidth, lack of technical support which remained barriers inhibiting web 2.0 activities. Challenges such as reliable electricity supplies, water resources, and comprehensive transportation system are still present in many African regions. Besides the electricity power distribution constraints, others barriers are related to the lack of technology transfer and investments which have big impacts on social networking, online marketing and corporate performance.

- Limited training of ICT applications and inadequate usage: There is a lack of computers or going online training. Inadequate skills in installation, operation and equipment maintenance further discourage several users [18]. Many companies and individuals still preferred using the Internet for simple research and communication purposes, but not for sophisticated tasks like E-commerce or E-HRM.

- Prohibitive cost of Internet and computer technologies: Godwin Onu, Professor at Nnamdi Azikiwe University discussed Internet penetration constraints by multitude socioeconomic and political challenges such as low computer skills and high cost for purchasing equipment such as computer-based, web-based, mobile device and videoconferencing technologies. Additional study found that internet connectivity in Africa is inadequate, expensive and poorly managed. In developing regions only few users are aware of the web 2.0 platforms opportunities. For instance in Niger the new technology is not yet mastered and computer equipment prices are beyond rural population's buying power. Considering that internet technologies are sophisticated; average population couldn't afford such supplementary costs and various citizens may prioritize the prosumption of merely basic goods (see Maslow's hierarchy of needs).

- Literacy or lack of ICT skills: this remains an important challenge in developing areas where the literacy and linguistic factors affect tremendously the use of technology tools. Lack of computer and technologies skills are limited also the use of web 2.0. A research published by the UN's educational, scientific and cultural body (UNESCO) indicates that 175 million young people lack even basic literacy skills [19]. Meaning, one in four young people in developing countries are unable to read a sentence. The report adds that over the past decade adult literacy remained excessively high as in 2011 there were still 774 million illiterate adults; "adult education have suffered from relative neglect, as attention focused on boosting primary school attendance rates in poor countries" said the report's director [19].

- Lack of Government support: Dubai WCIT (World Conference on International Telecommunications, 2012) divided countries' visions of Internet between decentralized vs. more centralized, loosely vs. tightly controlled, or open vs. closed. Some countries more open and ready for change adapt the Internet to their societies, whereas others prefer resisting to disruptions. Internet policymakers have some restrictions over access to content, online surveillance and monitoring, and limited companies' competition in the telecommunication sector [20].

Intriguingly, with recent explosion of the web 2.0, most African countries including Niger develop consistent tools to analyze populations' commentary on public concerns. Nicolas Seidler (2013) argues that there is a strong relationship between economic growth and the freedom to share information and ideas, therefore to efficiently conduct Africa economic activities online businesses need an open Internet environment [21].

- Others factors are related to the unemployment, poverty and frustration that limit the use of DIY digital technologies in developing areas [22].

\section{Conclusion and Recommendations}

There are various outcomes to adopt web 2.0 systems by countries' decision makers; not only for social networking, but also for a flourishing Internet economy. From web 1.0 to web 2.0 information and technology are considerably changing today's businesses for both developed and developing countries. Yet the web 2.0 technologies are still in its infancy stages in many developing countries but there is a great enthusiasm amongst users to develop their talents; consequently, governments and organizations at varied levels must remove challenges that limit its widespread in both urban and rural areas. For successful implementation of the web 2 best practices and strategies orientation in Africa, this paper recommends the following:

- Massive capital investment by national economies is essential to transmit high speed data technology all over the territory. Africa policymakers, rather than consider web-based technologies as luxury should recognize it 
as a mean to improve social and economic development as it facilitates communications, sharing knowledge and access to information [22]. Thus, enabling citizens to interact more actively has a huge socioeconomic impact.

- Improving availability of computers, mobile and wireless devices with a fast reliable internet bandwidth should facilitate connection access for all citizens. Moreover, reliable electricity such as solar power should be available through all countries.

- Governments should support innovation and research via Web 2.0 tools. To do so, collaborative networks of public-private partnerships, telecommunication network service providers should be improved in the continent [15].

- The use of visual images instead of text could be generalized in order to make technologies tools understandable in rural areas where participants lack functional literacy to access blogs, forums, and wikis, Facebook, Wechat, and YouTube which are most available social networks in developing countries. Moreover, training staff and e-learning programs should be available.

\section{References}

[1] Ritzer, G. and Jurgenson, N. (2010) Production, Consumption, Prosumption: The Nature of Capitalism in the Age of the Digital "Prosumer". Journal of Consumer Culture, 10, 13-36. http://www.sagepub.co.uk/journalsPermissions.nav http://dx.doi.org/10.1177/1469540509354673

[2] Teece, D.J. (1986) Profiting from Technological Innovation: Implications for Integration, Collaboration, Licensing and Public Policy. School of Business Administration, University of California, Berkeley.

[3] Stieglitz, N. and Heine, K. (2007) Innovations and the Role of Complementarities in a Strategic Theory of the Firm. Strategic Management Journal, 28, 1-15. http://dx.doi.org/10.1002/smj.565

[4] Barsky, E. and Purdon, M. (2006) Introducing Web 2.0: Social Networking and Social Bookmarking for Health Librarians. Journal of the Canadian Health Libraries Association, 27, 65-67. http://dx.doi.org/10.5596/c06-024

[5] Alexander, B. and Levine, A. (2008) Web 2.0 Storytelling. Emergence of a New Genre. EduCAUSE Review, 43, 40-56. http://net.educause.edu/ir/library/pdf/ERM0865.pdf

[6] Maniates, M.F. (2001) Individualization: Plant a Tree, Buy a Bike, Save the World? Global Environmental Politics, 1, 31-52. http://dx.doi.org/10.1162/152638001316881395

[7] Chatora (2012) Encouraging Political Participation in Africa: The Potential of Social Media Platforms. https://www.issafrica.org/uploads/SitRep2012_15Mar.pdf

[8] Konieczny, P. (2009) Governance, Organization, and Democracy on the Internet: The Iron Law and the Evolution of Wikipedia. Sociological Forum, 24, 162-192. http://dx.doi.org/10.1111/j.1573-7861.2008.01090.x

[9] Boyd, D. (2006) A Blogger's Blog: Exploring the Definition of a Medium. Reconstruction, 6.

[10] Herman, J.L., Osmundson, E., Ayala, C., Schneider, S. and Timms, M. (2006) The Nature and Impact of Teachers' Formative Assessment Practices (CSE Technical Report No. 703). CRESST, Los Angeles.

[11] Bilton, C. (2007) Management and Creativity: From Creative Industries to Creative Management. Blackwell Publishing, Hoboken.

[12] Fletcher, R. (2016) Gaming Conservation: Nature 2.0 Confronts Nature-Deficit Disorder. Geoforum. http://dx.doi.org/10.1016/j.geoforum.2016.02.009

[13] http://answersafrica.com/africa-internet-usage-statistics.html

[14] Darren Waters (2007) Africa Waiting for Net Revolution. BBC News, October 29.

[15] Gakio, K. (2006) African Tertiary Institutions Connectivity Survey (ATICS). http://www.gesci.org/files/Connectivity\%20in\%20African\%20tertiary\%20institutions.pdf

[16] Dadzie, P.S. (2009) E-Learning and E-Library Services at the University of Ghana: Prospects and Challenges. Information Development, 25, 207-217. http://dx.doi.org/10.1177/0266666909340791

[17] Lwoga, E. (2012) Making Learning and Web 2.0 Technologies Work for Higher Learning Institutions in Africa. Campus-Wide Information Systems, 29, 90-107. http://dx.doi.org/10.1108/10650741211212359

[18] Rhema, A. and Miliszewska, I. (2010) Towards E-Learning in Higher Education in Libya. Issues in Informing Science and Information Technology, 7.

[19] Internet World Stats (2011) Africa Internet Facebook Usage and Population Statistics. http://www.internetworldstats.com/africa.htm

[20] International Telecommunications Union (2012) ICT Data and Statistics (IDS). Global ICT Developments. 
http://www.itu.int/ITU-D/ict/statistics/ict/index.html

[21] Seidler, N. (2013) An Open Internet in Africa: Challenges Shifting beyond Access. Public Policy. https://www.internetsociety.org/blog/public-policy

[22] Fox, S. (2014) Third Wave Do-It-Yourself (DIY): Potential for Prosumption, Innovation, and Entrepreneurship by Local Populations in Regions without Industrial Manufacturing Infrastructure. Technology in Society, 39, 18-30.

\section{Submit or recommend next manuscript to SCIRP and we will provide best service for you:}

Accepting pre-submission inquiries through Email, Facebook, Linkedin, Twitter, etc A wide selection of journals (inclusive of 9 subjects, more than 200 journals)

Providing a 24-hour high-quality service

User-friendly online submission system

Fair and swift peer-review system

Efficient typesetting and proofreading procedure

Display of the result of downloads and visits, as well as the number of cited articles

Maximum dissemination of your research work

Submit your manuscript at: http://papersubmission.scirp.org/ 